\title{
Editorial
}

\section{And the Winner is...? Prizes and Awards in Arts and Culture}

\author{
Stevie Marsden ${ }^{1 *}$, Will Smith ${ }^{2}$ \\ ${ }^{1}$ CAMEo Research Institute for Cultural and Media Economies, University of Leicester, UNITED KINGDOM \\ ${ }^{2}$ University of Stirling, UNITED KINGDOM
}

*Corresponding Author: stevie.marsden@leicester.ac.uk

Citation: Marsden, S. and Smith, W. (2019). And the Winner is...? Prizes and Awards in Arts and Culture, Journal of Cultural Analysis and Social Change, 4(2), 09. https://doi.org/10.20897/jcasc/6353

Published: December 11, 2019

Keywords: awards, prizes, cultural industries, prize culture

\section{INTRODUCTION}

In a 2019 editorial for The Bookseller, the magazine's Deputy Editor, Benedicte Page, reflected on the joint awarding of that year's Booker Prize to Bernardine Evaristo and Margaret Atwood as another in a history of 'judging controversies' (Page, 2019). Cycles of commentary and response from industry figures and the media about the Booker judges' decision to break the prize's rule forbidding the splitting of the award (a rule instated in 1992 following a split award between Michael Ondaatje and Barry Unsworth) confirmed, Page argued, the Booker Prize as 'our most powerful literary award-controversies and all' (Page, 2019). Yet, while Page's silver-linings approach to the 2019 Booker Prize scandal focused on the controversy of a split award as good news for the industry, particularly booksellers who were 'delighted to have two Booker winners' (Page, 2019), it failed to acknowledge the imbalance of power and inequity of recognition that 'powerful' prizes like the Booker continue to instil. For many, the problem with the Booker being awarded to two writers was not the contravening of the prize's own rules, but the fact that the prize was split between Atwood, a white, internationally renowned, prior Booker winner, and Evaristo, one of only four black women to be shortlisted for the Booker in its fifty-one year history, and the only black woman to have won. Having Evaristo share what could have been a historic win with Atwood illustrated more than the fallibility of judging practices and the arbitrariness of selecting one 'best' book: it also revealed how the 'most powerful literary award' can wield that power in unfathomable and ultimately dissatisfying ways.

What was at the heart of the 2019 Booker Prize controversy was the underlying anxiety about what work a prize does. Gaby Wood, literary director of the Booker Prize Foundation, identifies the problem as 'the notion of judgement,' asking, 'is the conversation in the judging room actually the point, rather than the result?' (Sethi, 2019). Wood concludes that 'a prize like the Booker should be an investigation more than an act of judgement' (Sethi, 2019). Alongside this anxiety comes the direct question of what any particular prize itself is aiming to identify or 'investigate'. Bud McLintock, Director of the Costa Book Awards, issued guidance to the 2019 judges which set clear criteria that 'a 'Costa' book is a sparkling, eminently readable book with broad commercial appeal' (McLintock, 2019). Given that such candid discussions about the purpose or motivations of a prize are rarely debated in non-industry-focused public arenas (Wood was quoted in a trade magazine and McLintock's guidelines are an internal document written specifically for Costa judges), it would be fair to suggest that public consumption of prizes within culture more broadly aligns the purpose of a prize to the cultural product and work it celebrates. Certain prizes are viewed purely as judgements of the quality of a piece of work (e.g. Academy Awards), others are investigations into the ideologies of canon formation and value (e.g. Women's Prize for Fiction), and others aspire 
for discoveries of unknown or under-recognized talent (e.g. Jhalek Prize for Book of the Year by a Writer of Colour). But, in all cases a prize serves to invoke the authority to intervene outside pre-existing market data which might demarcate a cultural product's value, such as sales. Ultimately, however, since prize decisions arrive without consistent means of public understanding of judging labour, there is always room for critique and controversy.

Such critique and controversy is easily co-opted into the cyclical logic of the prize when longer sustained attention is absent, or feels impossible given the consistent emergence of further prize controversies. In the past year, there has been a swathe of prize controversies across the cultural and creative industries, ranging from the sponsorship of prizes (The BP Portrait Award ${ }^{1}$ ); the integrity of those recognised (The Nobel Laureate ${ }^{2}$, The Palme d'Or ${ }^{3}$ ), and, as a result, the awarding institutions (Swedish Academy ${ }^{4}$ ); charges of nepotism (Pulitzer Prize for general nonfiction ${ }^{5}$ ); and the rescinding of awards (the Nelly Sachs prize ${ }^{6}$ ). Whilst these controversies fuel interest in such awards, they also hint at attempts to examine the broader logics and criteria of the recognition provided by cultural awards. They force us to ask questions about who is being awarded, why they are being celebrated, and whether they should be receiving awards at all. Yet, this generalised critique instigated by and located in the spectacle of controversy relies on public dissent, often fuelled by feverish, and oftentimes exaggerated, media commentary, and potentially narrows the possibilities for attending to the complex operations of a staggering number of cultural awards.

Despite the groundswell of scholarly approaches to prize culture, which provides a variety of methods for interrogating individual prizes (Griffith, 2015; Moeran, 2012; Roberts, 2011; Todd, 1996; Wu, 2002) and the interconnected network of awards and circulations of value (English, 2005; Squires, 2004), the work of and within cultural prizes continues to be a rich and dynamic area of critical examination. Yes, despite their influential role and placement within the cultural economy prizes remain markedly under-examined. Indeed, prizes and awards in arts and culture are staples of the cultural calendar. Every year there will be Oscars buzz, Booker speculation and Golden Globe predictions. Such prizes are spread throughout the year, so we need only wait a few weeks for another shortlist announcement or awards ceremony to feed our prize cravings.

\section{And the Winner is...? Prizes and Awards in Arts and Culture}

This special issue, 'And the Winner is...? Prizes and Awards in Arts and Culture', is the latest contribution to a field of academic examination which aims to understand the prevalence, impact and underlying principles of prizes in arts and culture. This issue emerged from a one-day research symposium hosted by CAMEo Research Institute for Cultural and Media Economies at the University of Leicester, which brought together an interdisciplinary group of scholars to share their research on cultural prizes. Anna Auguscik's opening keynote on the day, 'What is an award? Methods, Media, and the Man Booker Prize', pinpointed many important methodological questions around identifying and recording the rhythm, scope and scale of an individual award that would echo throughout the rest of the day. Indeed, what became clear over the course of the symposium, during which presenters discussed prizes for music, film, food and drink, and literature, is that while there are core similarities to prizes no matter what cultural endeavour they celebrate, there are also critical nuances which we need to understand in order to fully comprehend the wider ecosystem of prize-giving and receiving.

Accordingly, the articles gathered in this special issue take on quite different topics, but they all draw on core theorists who have become key figures in the field of prize culture analysis. The scholars in this special issue employ

\footnotetext{
1 “Scottish Gallery to Pull BP Portrait Award Exhibition from 2020.” BBC News, 11 Nov. 2019. Available at:

https://www.bbc.co.uk/news/50374910 (Accessed November 25, 2019)

2 Oliver Moody, “Nobel Prize Goes to Writer Peter Handke Who 'Fuelled Ethnic Hatred'.” The Times, 11 Oct.2019. Available at: https://www.thetimes.co.uk/article/nobel-prize-goes-to-writer-peter-handke-who-fuelled-ethnic-hatredf6xgr5bvc (Accessed November 25, 2019)

${ }^{3}$ Lucy Pavia, “Cannes Head Defends Honorary Palme D’Or for 'Sexist' Alain Delon.” Evening Standard, 14 May 2019, https://www.standard.co.uk/insider/alist/alain-delon-palme-dor-cannes-film-festival-controversy-a4141546.html. (Accessed November 25, 2019)

${ }^{4}$ Ron Charles, "The Swedish Academy Took a Year off to Fix the Nobel Prize in Literature. It's Still Broken." The Washington Post, 11 Oct. 2019. Availale at: https://www.washingtonpost.com/entertainment/books/the-swedish-academytook-a-year-off-to-fix-the-nobel-prize-in-literature-its-still-broken/2019/10/10/23f1b6da-eb7d-11e9-9306-

47cb0324fd44_story.html (Accessed November 25, 2019)

${ }^{5}$ Valerie Richardson, "Pulitzer Prize Administrator Defends Process after Prize Goes to Board Member's Wife." The Washington Times, 22 Apr. 2019. Available at: https://www.washingtontimes.com/news/2019/apr/22/pulitzer-prizeadministrator-defends-process-after/ (Accessed November 25, 2019)

${ }^{6}$ Porter Anderson, “Kamila Shamsie’s Rescinded Nelly Sachs Prize Fuels Criticism.” Publishing Perspectives, 27 Sept. 2019. Available at: https://publishingperspectives.com/2019/09/kamila-shamsie-rescinded-nelly-sachs-prize-fuels-criticism/ (Accessed November 25, 2019)
} 
the research of James F. English, Claire Squires, John Street, Brian Moeran and Nicola Griffith to understand the ways in which prizes are imagined, created and allocated. Through examinations of nascent prizes, dead prizes, industry prizes and civic prizes, each article interrogates the politics of value within arts and cultural industries.

We open the issue with Stevie Marsden and Claire Squires. Marsden and Squires' work draws attention to the administration and judging of awards, and the critical issues that both roles encounter. Based on their experiences as an embedded $\mathrm{PhD}$ researcher and prize administrator (Marsden) and $\mathrm{PhD}$ supervisor and literary award judge (Squires) for the Saltire Society Literary Awards, Marsden and Squires use autoethnography to shed light on the inner workings of book prizes. Considering how change might be instigated by research findings and the evidence produced by debates on gender imbalance in Scottish literary award culture, authors examine the difficult duality of their roles and the seeming inevitability of their intersection. Christina Neuwirth expands upon these autoethnographic methodologies in the next article of this issue, examining her own complex role(s) as an embedded researcher within ROAR (Represent, Object, Advocate, Rewrite), a group working to combat inequality in Scottish writing and publishing. Neuwirth's affiliation with ROAR is part of her ongoing PhD research project analysing diversity in Scottish publishing and the efficacy of interventions, such as a new prize for Scottish women writers, to combat inequality. Neuwirth explores how her researcher-in-residence role means operating as a 'speculative archivist,' deciding which documents, conversations and statements merit inclusion in a prize archive yet-to-be. Her reflexive approach evaluates what sources prove most important in beginning the development of a prize.

Following this, Emma-Jayne Reekie focuses on civic honours, using a statistical framework to examine how the British Honours System has responded to the music industry. Set in the context of awards which broadly identify contributions to public life, and where a number of understandings of public value converge, Reekie outlines a change from proxy expressions of music's value, via economics, entertainment or charity, to a legitimation of a cultural industry where individuals are now honoured for their 'services to music'. Reekie's paper illustrates how the monarchical and political institutional context of the British Honours System makes its engagement with popular music and exchanges of value uniquely complex. After Reekie, Will Smith considers the history of a now-defunct literature prize, the Constable Trophy, which, in collaboration with London publisher Constable, intervened to encourage the development of new writing by writers resident in the North of England. Smith draws comparisons to contemporary award initiatives to encourage regional diversity in British publishing, and the benefits of re-appraising the work of defunct prizes. Like Reekie, Smith demonstrates how piecing together a detailed history of an award, via the triangulation of data, such as archival records, contemporaneous media coverage, and, in Smith's case, interviews with those once involved with the award, not only facilitates a deeper understanding of how a prize functions or has functioned, but also illustrates the lasting impact of such awards and their influence on culture today.

Our final article, and the proverbial nightcap to this special issue, is Thomas Thurnell-Read's examination of prizes in craft gin production. Based on interviews with twenty gin producers from around the UK, ThurnellRead's analysis reveals that, while the conferral and receiving of awards has become central to artisinal food and drink culture in recent years, there is a sense of unease towards such awards. The interviews reveal questions of legitimacy around industry prizes, particularly in terms of judging practices, prize originations and promotional influence.

James F. English notes that it is in 'the specific workings of prizes - their elaborate machineries of nomination and election, presentation and acceptance, sponsorship, publicity, and scandal' that the 'arrangements and relationships that have come to characterize the field' (English, 2005: 4) can be found. These machineries are often off-stage, outside of the media glare and opaque to consumers. Unacknowledged work of administration, organisation and criteria of eligibility orchestrates and supports the definition of what an award or prize is for, only tentatively erupting into the glare of scrutiny via the medium of scandal or controversy. As the articles in this special issue illustrate, examining the nuanced workings of cultural prizes - from their administration, influence and impact, to their (potential) creation and expiration - enables us to understand not only how prizes work within the context of prize culture, but also how they function within popular culture more broadly.

\section{REFERENCES}

English, J. (2005). The Economy of Prestige: Prizes, Awards and the Circulation of Cultural V alue. Cambridge: Harvard University Press. https://doi.org/10.4159/9780674036536

Griffith, N. (2015). Books about women won't win big awards: some data. Available at: https:/ / nicolagriffith.com/2015/ 05/26/books-about-women-tend-not-to-win-awards/ (Accessed November 25, 2019).

McLintock, B. (2019). "Judging Guidelines" Costa Book Awards, 2019.

Moeran, B. (2012). Awarding a Prize: An Ethnography of a Juried Ceramic Art Exhibition in Japan. Paper presented at 7th Conference of the European Research Network Sociology of the Arts. 5-7 September. Vienna, Austria.

(C) 2019 by Author/s 
Page, B. (2019). Winning ways. The Bookseller, October 25, 5. Available at: https://www.thebookseller.com/ blogs/winning-ways-1103996 (Accessed November 25, 2019).

Roberts, G. (2011). Prizing Literature: the Celebration and Circulation of National Culture. Toronto: University of Toronto Press. https://doi.org/10.3138/9781442694583

Sethi, A. (2019). FutureBook Live: On Getting Books to the Top of the Cultural Agenda. The Bookseller, November 13. Available at: https:/ / www.thebookseller.com/blogs/futurebook-live-getting-books-topcultural-agenda-1113256 (Accessed November 25, 2019).

Squires, C. (2004). A Common Ground? Book Prize Culture in Europe. Javnost - The Public Journal of the European Institute for Communication and Culture, 11(4), 37-47. https:// doi.org/10.1080/13183222.2004.11008866

Todd, R. (1996). Consuming Fictions: The Booker Prize and Fiction in Britain Today. London: Bloomsbury.

Wu, C. (2002). Privatising Culture: Corporate Art Intervention Since the 1980s. London: Verso. 